\title{
BMJ Global Health Conflict, sanctions and the struggles of Syrians for food security in the shadow of the UN Food Systems Summit 2021
}

\author{
Haroutione Selimian, ${ }^{1}$ Marie Nassr (D) , ${ }^{2}$ Kasturi Sen ${ }^{3}$
}

To cite: Selimian H, Nassr M, Sen K. Conflict, sanctions and the struggles of Syrians for food security in the shadow of the UN Food Systems Summit 2021. BMJ Global Health 2022;7:e007477. doi:10.1136/ bmjgh-2021-007477

Handling editor Seye Abimbola

- Additional supplemental material is published online only. To view, please visit the journal online (http://dx.doi.org/10. 1136/bmjgh-2021-007477)

HS, MN and KS are joint first authors.

Received 21 September 2021 Accepted 7 December 2021

Check for updates

(C) Author(s) (or their employer(s)) 2022. Re-use permitted under CC BY-NC. No commercial re-use. See rights and permissions. Published by BMJ.

${ }^{1}$ President, Armenian Protestant Community, Aleppo, Syrian Arab Republic

${ }^{2}$ International Council for Fair Trials and Human Rights, Damascus, Damascus Province, Syrian Arab Republic

${ }^{3}$ University of Oxford Wolfson College(CR), Oxford, UK

Correspondence to

Dr Kasturi Sen;

kas.sen@wolfson.ox.ac.uk

\section{INTRODUCTION}

In the shadow of the COVID-19 pandemic, the Afghan debacle and the conclusion of the UN Food Systems Summit (UNFSS) in September 2021, those of us living in conflict zones have once again been left out of international agendas. ${ }^{1}$ It is remarkable that the UNFSS excluded mention of conflict zones in its core agenda and at the preconference meeting in Rome. ${ }^{1}$ In the MENA region alone this means more than 200 million people continue to live with conflict and hunger in a context that is largely man made and much of it due to unilateral coercive measures (UCMs) outside of the jurisdiction of international law and approval of the UN Security Council (UNSC). Recent surges in fighting and the spillover effects of a protracted conflict in Syria mean that all parties contribute to violence and food insecurity. ${ }^{2}$ Hunger and food insecurity in Syria and elsewhere is linked not only to military interventions such as sieges increasingly prevalent in war zones but also linked to humanitarian blockades such as those involving unilateral sanctions as is the focus of this paper.

Following more than a decade of conflict, families across Syria are facing unprecedented levels of poverty and food insecurity. Severe humanitarian needs persist with a record number of Syrians are now food insecure. $^{3}$ Their voice however has been largely drowned by a privileged 'opposition' funded mostly by western governments, whose main focus has been on regime change. The voices of ordinary Syrians living inside Syria have been drowned out as highlighted in online supplemental video 'Voices from Syria'.

Large-scale hostilities and mass displacement across the northern governorates, combined with a severe economic downturn, mean that the overall food security situation has continued to deteriorate across the country, with families requiring urgent
Summary box

The exclusion of conflict zones and countries under sanctions from the agenda of the UN Food Systems Summit (UNFSS) held in September is a majo oversight since in the Middle East and North Africa (MENA) region alone more than 200 million civilians are affected by conflict, hunger and food insecurity, while globally the numbers are several fold greater with Syria leading the world in refugee displacement.

- A politicised agenda for regime change over the past decade has overlooked the right to food of Syrian civilians in particular those in areas under control by the government of Syria. (70\% of land) and well documented significant impact of sanctions in this region, for the people's physical and mental health.

- Unilateral coercive measures (UCMs) are blunt instruments repeatedly condemned by the UN Human Rights Council as outside of international law and man-made tools of hunger and deprivation, increasingly recognised as a failed strategy for 'regime behaviour change'. Their humanitarian impacts are neglected or denied as part of widespread complacency among sending countries as reflected in the agenda of the UNFSS.

- Any follow-up of the UNFSS needs to consider conflict zones and UCMs as applied to Syria and other countries, as a major obstacle to food security with their scatter effects on the whole economy where food, medicines and the health systems as a whole are affected and should be reassessed to support the right to life, to food and for the prospect of targeted countries meeting Sustainable Development Goal (SDG) goals.

support to meet basic needs and rebuild their lives. ${ }^{35}$

The World Food Programme (WFP) estimates more than 12.4 million Syrians are now food insecure. This is an increase of 4.5 million in the last year alone and the highest number ever recorded. Years of conflict, displacement, soaring food prices and a collapse in the value of the Syrian pound have affected the lives and nutritional status of some of the 


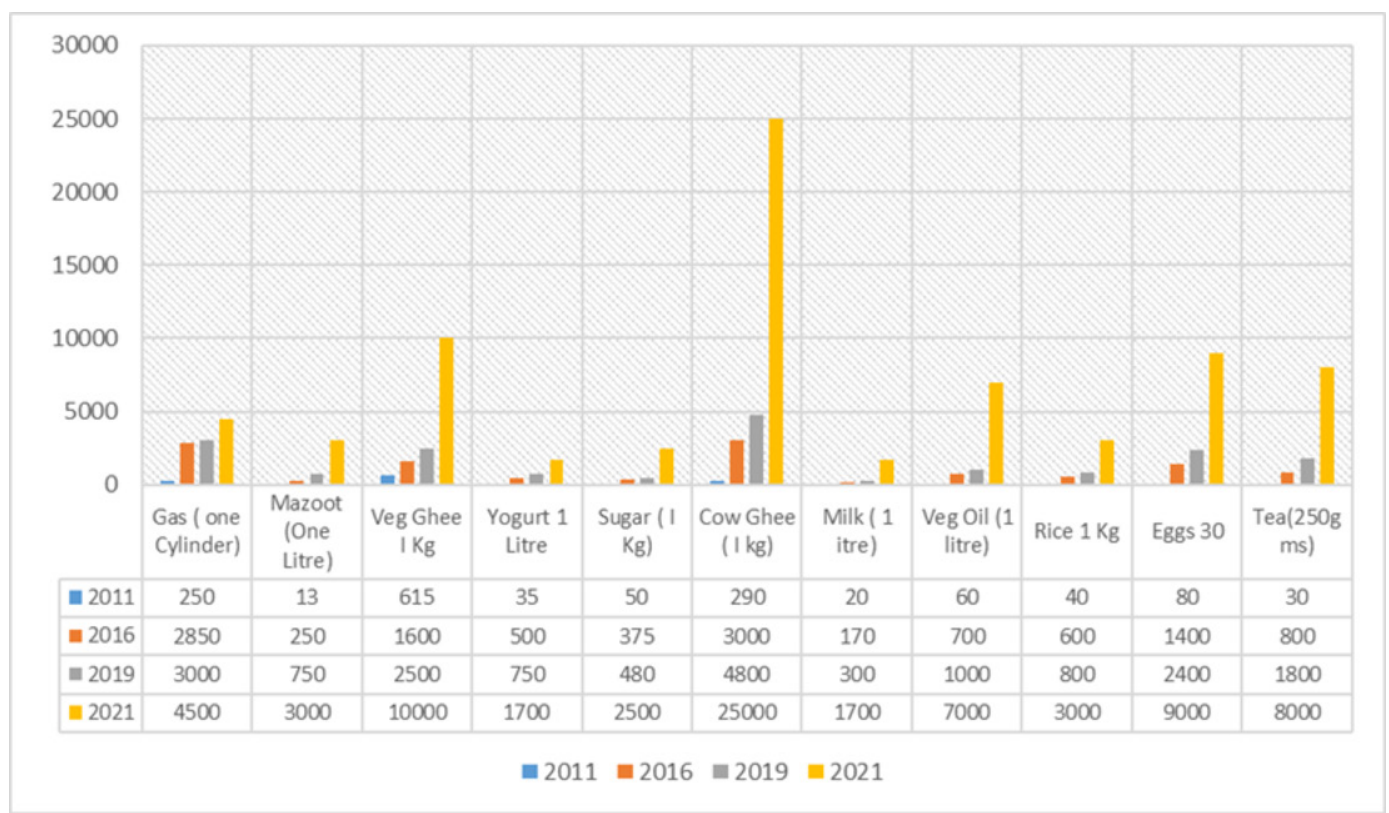

Figure 1 Cost of food and basic essentials in Syria (2011-2021). Source: Compilation from two sources: http://www. hamafree.com/index.php?name=news\&op=view\&id= (adjusted to May 2012 rates for rice and milk) (figures 2020-2021) from World Food Programme. Country Brief Syria (2021). Value of Syrian 1 Lira in US\$ 2010 (47). Value of 1 Syrian Lira to US\$ in 2021 (1258). Mazoot=heating oil.

country's most vulnerable people, women children and the elderly in particular. Today, more parents than ever before are struggling to feed their children.

The price of basic food items is now 29 times higher than precrisis averages. ${ }^{5}$ The physical and mental health impact of such deprivation has been well documented by all UN agencies including the WHO but to little avail. ${ }^{67}$ The high cost of food together with the recent reductions in food subsidies has led to families cutting meals from three to two per day in the worst affected regions. Other coping strategies reported to a WFP survey include removing children from school to work for additional income and a $25 \%$ increase in early child marriage in Lattakia, Deir ez Zor, Quneitra and Lattakia. ${ }^{3}$ Such extreme levels of hunger and food insecurity were unknown to Syria prior to the conflict. ${ }^{8}$ While prolonged conflict is a factor in poverty, hunger and food insecurity, UCMs target key sectors of the economy that have spillover effects which do not spare so called 'exempted' goods such as food and medicine. ${ }^{9-11}$

Figures 1-3 highlight the rising cost of basic essentials over the decade of conflict on the rising cost of fuel and wheat for households in the past 2 years alone. The relationship with UCMs is both direct (restrictions on fuel for cooking and heating) and indirect in terms of the scatter effects of UCMs on banking, trade and finance.

\section{Wheat flour prices in three regions of Syria}

The price of one kilo of flour in Syrian pounds

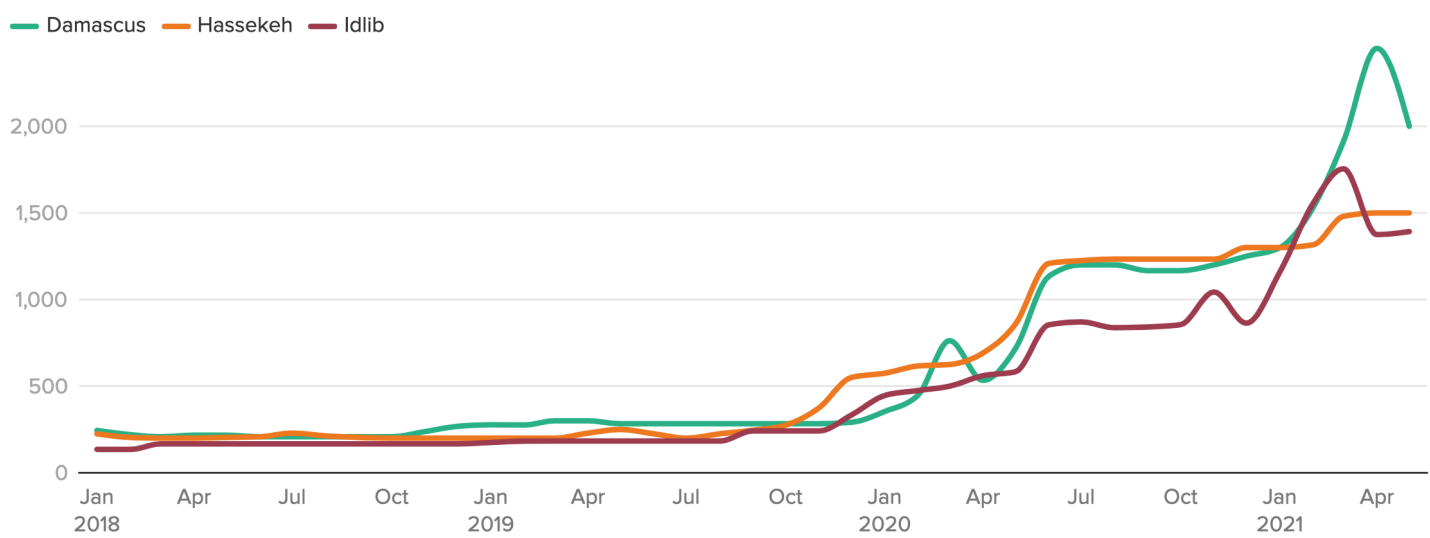

Figure 2 Scatter effects of unilateral coercive measures on basic essentials for food security (2018-2021). 


\section{Cooking gas prices in Syria}

Parallel market price for one cylinder in Syrian pounds

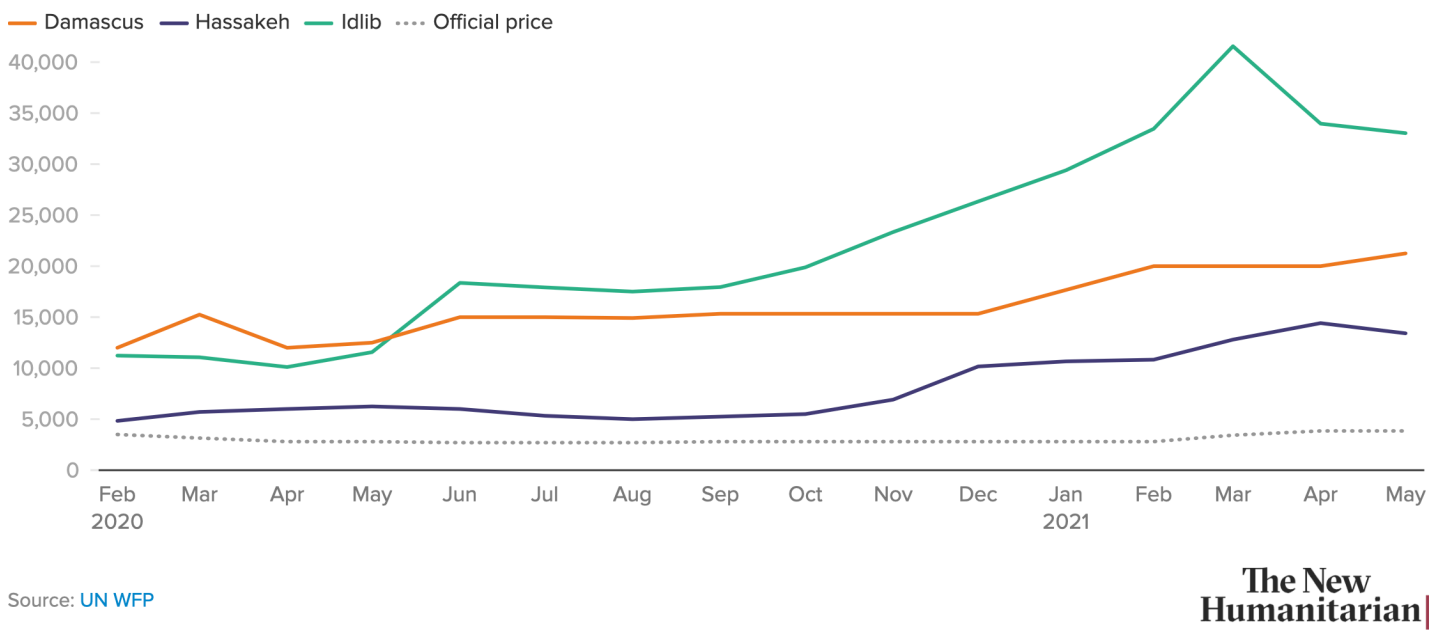

Figure 3 Scatter effects on basic essentials for food security (2018-2021).

\section{WHAT ARE UCMS AND HOW DO THEY IMPACT ON FOOD SECURITY}

There is contested opinion on the use of UCMs as a tool to alter the behaviour of outcaste regimes. First, they are neither ratified by the UN nor have legitimacy. ${ }^{12} 13$ They also set a precedent for rogue behaviour among sending nations as "coercive diplomacy'. ${ }^{12-14}$ Second, while in theory they aim at improving regime behaviour towards its citizens, in reality the effect is the opposite due to their disproportionate impact on the economic security of the citizens it deems to protect. This merely pushes those citizens to extreme hardship. ${ }^{12-15}$ Furthermore, the longer they are applied for, the worse are the conditions for civilians with the least likelihood of their effectiveness either for a change in regime behaviour or in protecting citizens. ${ }^{16-18}$ Most of all, targeting key sectors of country's economy to alter regime behaviour has 'scatter effects' on all sectors, including for the supply of food and of medicines-both considered exempt. While 'smart' sanctions against Syria and other countries of the region have also been applied targeting individuals in authority and their allies, UCMs on the other hand have a broader sweep, targeting banking, trade, finance and the sale and supply of fuel classed as 'dual use' goods that supposedly can be used for war. Thus, UCMs also have major role to play in the collapse in the value of the Syrian pound that has a direct impact on households capacity to purchase essentials such as food, fuel and medicines. ${ }^{9}$

One problem identified by Walker and $\mathrm{Al}$ Jazairy is the wide definition of dual-use products. Items flagged as dual use reportedly include: nitrous oxide (used for anaesthetics not only in hospitals but also to make bombs), agricultural fertiliser and pesticides, certain drilling tools, pipes and chlorine products used for water purification and sanitation (and as chemical weapons), construction equipment, computers and IT equipment and power generators. Even importing spare parts for dialysis machines reportedly runs into a 'labyrinth of legal injunctions'. ${ }^{9-11}$
While the EU claims its UCMs are designed to spare civilians and include exemptions for humanitarian needs and purposes, the absence of regular monitoring or discussion of humanitarian impact has negative effects from the scatter effects of UCMs and the more recently imposed US Caesar Sanctions (2020). ${ }^{8} 19$

US sanctions against Syria in place since 1979 have taken a severe turn as the 'Caesar' sanctions in 2020. These sanctions were applied ostensibly to create accountability for 'crimes' of the Syrian state and its allies Russia and Iran during the decade of conflict. In practice, they prevent any foreign investors from doing business with the Syrian government because secondary sanctions will be applied to those who breach these terms. This prevents any prospect of post war reconstruction of the country and economy since they also have what experts describe as a 'chilling effect' preventing trade and supplies even in permissible goods by companies and traders, in fear of breaching US and EU rules. ${ }^{9-11}$ Subsequently there are damaging consequences for food supply and medicine availability. ${ }^{920}$ The important underlying motivation for UCMs more generally has been to bypass the UNSC because there has been no consensus on the imposition of broad sanctions on Syria's economy, due to vetoes from Russia and China.

Figure 4 below illustrates how UCMs have a spillover effect on the wider economy, including money supply, collapsed money value, employment, and for exempted goods such as food and medicine. All of these reinforce household poverty already damaged by a decade of conflict. A number of scholars, researchers and sanction experts have argued that a focus on governance and a 'legal' compulsion from UCM sending countries simply deny civilians already suffering from protracted conflict of their basic rights. ${ }^{180}$

over the past 10 years of war, it has rarely been easy for Syrians to get the fuel that powers electricity plants, factories, hospitals, gas stoves and home heaters. As Myriam Youssef, a 
Impact of the crisis on the Syrian economy

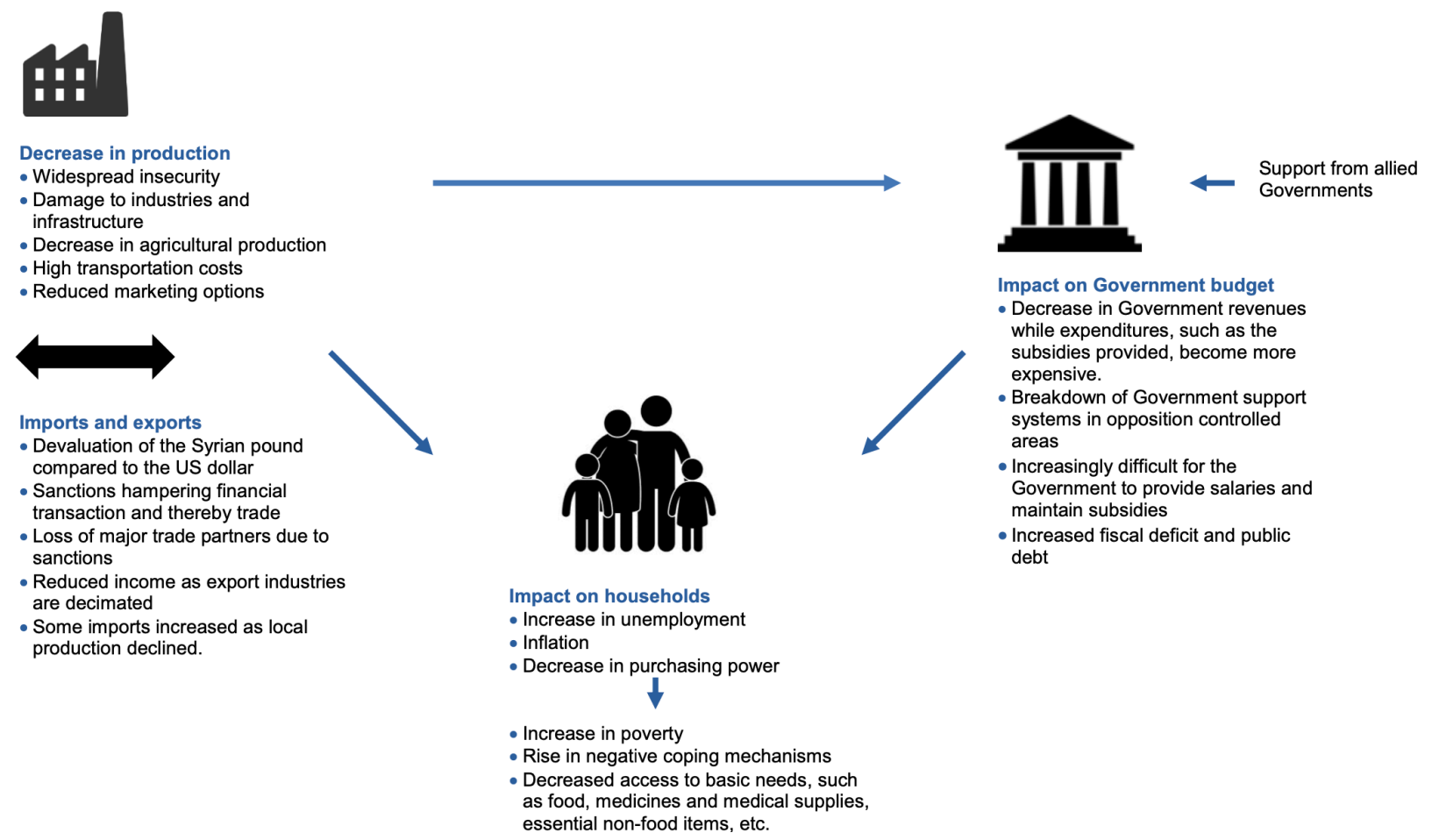

Figure 4 The scatter effects of UCMs. Source: Impact of the conflict on Syrian economy and livelihoods Syria Needs Analysis Project-July $2013 .{ }^{22}$ UCMs, unilateral coercive measures.

Damascus-based researcher with the London School of Economics, wrote in February, 'like many winters past, our days are drained by hours upon hours of waiting... we wait for fuel distribution vehicles to pass by our neighbourhood so that we buy a few litres, enough to warm the house for a couple of hours. ${ }^{9}$

\section{SANCTIONS-THE FUTURE}

According to UN Special Rapporteur for Human Rights, the world is facing an extraordinary expansion in the scope, grounds, purposes, targets, means and the extraterritoriality of unilateral sanctions. Douhan argues that this is taking place due to the absence of a universally recognised definition of what UCMs constitute. She claims this has resulted in an increasing violation of the rule of law by states with serious humanitarian consequences. $^{12}$

unilateral measures may be taken by states or regional organisations only in compliance with international legal standards: if they were authorised by the Security Council, acting under Chapter VII of the Charter of the United Nations, in response to a breach of peace, a threat to peace or an act of aggression; if they did not violate any international treaty or customary norm of international law or if their wrongfulness was excluded in accordance with international law in the course of countermeasures, in full compliance with the rules of law of international responsibility, including the obligation to guarantee that fundamental human rights were not violated. Unilateral sanctions that did not satisfy the above criteria constituted UCMs and were illegal under international law and characterised the majority of UCMs being applied at present. ${ }^{21}$
As a result, innocent civilians experience their economic, social and health impacts. The focus of the UNFSS, for example, is about the right to sustainable food but as with people from many parts of the world we question whether UCMS have much to do with protection of human rights or rather more to do with an abysmally failed geopolitical strategy primarily aimed to furthering economic and political interests of 'western' powers. However, it is citizens who ultimately suffer from the resulting lack of investment in basic services and infrastructure that has triggered an ongoing humanitarian and health crisis.. ${ }^{22}$ Given the legacy of a conflict that has ripped apart a country and its people for more than 10years, leaving 6.2 million people internally displaced and over 12 million people in need of humanitarian assistance, it is staggering that civilians must face further suffering, inflicted and compounded manifold by UCMs. They cannot be labelled as were the victims of sanctions on Iraq as 'collateral damage' whose effects on children in Syria are highlighted by WHO's support for severely malnourished children through its stabilisation programmes in different regions of the country (http://www.emro.who. $\mathrm{int/syria/news/who-maintains-support-to-stabilization-}$ centres-to-save-innocent-lives-in-syria.html). ${ }^{23}$

\section{COVID-19 AND SANCTIONS}

Furthermore, sanctions are disproportionately affecting Syria's response to the COVID-19 pandemic and the Syrian healthcare system. Several observers of the Syrian health system describe sanctions as 'blunt bilateral instruments' that have not been approved by the UNSC and 
opposed by the UN Commission on Human Rights and which were imposed on Syria in the unsupported belief that they will hasten regime change. Sanctions have seriously impeded the country's ability to cope with the pandemic with the Syrian health system, already fractured by years of conflict, being further destroyed by sanctions. ${ }^{82}$ An appeal in the Guardian newspaper by a Syrian medic (2020) described sanctions related shortages of equipment in the following terms:

I appeal to the international community and UN agencies to take urgent measure to support our hospitals, local organizations and the health care system by providing more testing capacity, PCR machines, testing kits, medication PPE, medical supplies, oxygen machines and ventilators. We understand that medical and humanitarian support is exempted from any international sanctions. I urge UN agencies and local health authorities to ensure that distributing life-saving medical supplies is based on a transparent process of needs, monitoring and evaluation without any delay or bottle necks. ${ }^{25}$

\section{CONCLUSION}

The evidence we among others have collected from Syria show that so called targeted 'countermeasures' rarely function as 'targeted'. Such measures should be reviewed on a regular basis for their humanitarian impact. Their impact, for example, on the value of the currency, on livelihoods, on trade and most importantly on food security must be addressed. The UN has repeatedly discouraged nations from imposing unilateral measures on nations, since they mostly impact on civilians (as we learnt from Iraq) and are against international humanitarian lawthe right to life, to food and be able to live in dignity. There cannot be a wall of silence on this issue as they are geopolitically driven, man-made tools of hunger and deprivation. Furthermore, the UNTSC (Targeted Sanctions Consortium) ${ }^{26}$ argues that such sanctions contribute to a shadow economy, hoarding and criminality further undermining humanitarian access, the prospects for peaceful reconstruction or any chance of meeting the SDGs. Now is the time, as with exclusion of conflict zones from the agenda of the UNFSS, to stop the blame game and adopt a more objective approach.

For the past decade, a distorted view of Syria has been promoted through the media and in academic journals, because the primary concern has been a powerful narrative for regime change. We as citizens from the government held areas of Syria urge the international communities present at the UNFSS and in and follow-up meetings to reassess their priorities and foreign policy initiatives on food security. We urge them not to neglect the dire situation of conflict zones that prolongs hunger and suffering in Syria and elsewhere. It is the poor who bear the brunt of these actions.

Twitter Marie Nassr @MarieBelle1012

Acknowledgements The authors are grateful for comments and suggestions from the reviewer.
Contributors HS wrote the first draft. MN and KS edited and worked on the second draft. MN produced figure 1. KS formatted and edited the final draft and made the submission following comments and final reading from HS and MN. The response to the reviewer and the revised draft was prepared by KS, read and commented on by MN and HS and submitted by KS.

Funding The authors have not declared a specific grant for this research from any funding agency in the public, commercial or not-for-profit sectors.

Competing interests None declared.

Patient consent for publication Not applicable.

Ethics approval This study does not involve human participants.

Provenance and peer review Not commissioned; externally peer reviewed.

Data availability statement Data are available in a public open access repository. Corresponding author says that they are all from published reports.

Open access This is an open access article distributed in accordance with the Creative Commons Attribution Non Commercial (CC BY-NC 4.0) license, which permits others to distribute, remix, adapt, build upon this work non-commercially, and license their derivative works on different terms, provided the original work is properly cited, appropriate credit is given, any changes made indicated, and the use is non-commercial. See: http://creativecommons.org/licenses/by-nc/4.0/.

\section{ORCID iD}

Marie Nassr http://orcid.org/0000-0003-2209-7926

\section{REFERENCES}

1 United Nations. United nation food systems Summit-Pre Summit programme. Rome,Italy: United Nations, 2021.

2 United Nations Syria Commission for Human Rights. Increasing violence and fighting add to Syria's woes, making it unsafe for return. New York, UN, 2021.

3 World Food Programme. Syria country brief. Rome, Italy: World Food Programme, 2021.

4 Le Corf P. Voices from Syria. Aleppo, Syria, 2021. https://drive. google.com/file/d/1p_SEEmeoR6ghiTfjk-VrhhL8AyRWGpOz/view? usp=sharing

5 World Food Programme. Syria country office market price watch Bulletin 78. Reliefweb, 2021.

6 World Health Organization. Addressing the silent impact of War- who expands mental health care services across Syria. Geneva: WHO, 2017.

7 World Health Organization. Mental health Syria. Syria: Damascus online, WHO, 2021.

8 Hussain HY, Sen K. Eu guidance impedes humanitarian action to prevent COVID-19 in Syria. Lancet Glob Health 2020;8:e1112-3.

9 Lund A. Just how" smart" are sanctions on Syria? The New Humanitarian, 2021. https://givinghopeforthem.com/2021/08/06/thenew-humanitarian-syrias-bread-crisis-in-graphs/

10 UNOCHA. Warning on Sanctions- affecting civilians, 2018.

11 Walker J. Study on Humantarian impact on Syria related unilateral Restritive measures. Beirut, Lebanon: UNESCWA, 2016: 1-42.

12 Douhan A. Special Rapporteur on unilateral coercive measures to the human rights Council: the overwhelming majority of unilateral measures applied today are illegal under international law. OCHA 2021: 1-7.

13 Gibson R. Geopolitical Coercion and the Implications for Global Health:Unilateral Sanctions as Unregulated Aggression: Population Health, Crimes Against Humanity, and the World Order. Canada: University of British Columbia, 2021.

14 Ronzitti N. Introduction. Cooercive diplomacy: sanctions and international law. Brill Niijoff, 2016: 190-206.

15 UN Human Rights Council. Report of the special Rapporteur in the negative impact of unilateral Coorcive measures on Syria on the enjoymentof human rights. A/HRC/39/54/Add.2, 1-15. Geneva: United Nations, 2018.

16 Biersteker T, Sue E, Tourhino M. Designing United Nations Targeted Sanctions: Intitial Findings of the Targeted Sanctions Consortium(TSC): Evaluating Impact and Effectiveness. Geneva, Switzerland: The Graduate Institute UN targeted sanctions consortium, 2012: 1-41.

17 Moret ES. Humanitarian impacts of economic sanctions on Iran and Syria. European Security 2015;24:120-40.

18 Peterson Institute for Int. Economics. Targeted sanctions: a policy alternative, 2000.

19 United Nations Office of the Human Rights Commission. Report of the special Rapporteur on the negative impact of unilateral coercive 
measures on the enjoyment of human rights on his mission to the Syrian Arab Republic. A/HRC/39/54/Add2. Geneva: United Nations, 2018: 1-14.

20 Ghisn Z. How economic sanctions negatively affect the health secto in Syria- a case of the pharmaceutical industry. LSE, 2020.

21 Douhan A. Special Rapporteur on the negative impact of the unilateral coercive measures on the enjoyment of human rights. AHRC-45/7. Geneva: UN Human Rights Commission, 2021: 1-19.

22 Reliefweb. Why economic sanctions on Syria must stop. HART, 2020.

23 WHO. WHO maintains support to stablization centes in Syria to save innocent lives. Damascus, Syria: WHO, Syria, 2021. http://www. emro.who.int/syria/news/who-maintains-support-to-stabilizationcentres-to-save-innocent-lives-in-syria.html

24 Sen K, Al-Faisal W, AISaleh Y, Fasial WA, Yasser SY. Syria: effects of conflict and sanctions on public health. J Public Health 2013;35:195-

25 The Guardian London. Comment is Free-Anonymous. I work as a medic in Syria where an unreported Covid-19 crisis is unfolding. 1 2021.

26 Biersteker T, Tourinho M, Eckert SE. The Effectivenes of United nations targeted sanctions. Geneva: Targeted Sanctions Consortium, The Graduate Institute Geneva, 2013: 1-51. 